\title{
Diagnosing sub-acute rumen acidosis in cows in the post-calving period with digital technologies
}

[Diagnóstico de acidose ruminal subaguda em vacas no período pós-parto usando tecnologias digitais]

\author{
A.S. Dorokhov, Y.A. Ivanov, V.V. Kirsanov, D.Y. Pavkin, F.E. Vladimirov**
}

Federal State Budgetary Scientific Institution - Federal Scientific Agroengineering Centre VIM - Moskow, Russian Federation

\begin{abstract}
This study aims to determine the relationship between indicators of the motor activity, $\mathrm{pH}$ factor, rumen and rectal temperature within 10 days after calving and to analyze the possibility of using the studied parameters as prognostic signs for diagnosing sub-acute rumen acidosis (SARA). The measurements were taken using bolus with sensors designed to monitor cow health. The motor activity, $\mathrm{pH}$ factor and ruminal temperature of 10 cows were measured during 10 days at a measurement interval of every 60 seconds. Next, the researchers calculated the average values of the obtained readings, which were divided into 2 groups according to a measurement interval of every 12 hours. Rectal temperature was measured using a veterinary thermometer every 12 hours (at 8 a.m. and at 8 p.m.). As a result, 200 measurements were obtained. Descriptive sampling statistics were calculated using the SPSS Statistics program. An increase in motor activity reduces the $\mathrm{pH}$ level of the rumen environment. Lowering the $\mathrm{pH}$ factor of the rumen environment leads to an increase in ruminal temperature. There is a positive statistically significant correlation between ruminal and rectal temperature. The nosology of SARA can be predicted by measuring the motor activity and rectal temperature of dairy cows.
\end{abstract}

Keywords: cattle, rumen, SARA, $\mathrm{pH}$ factor, temperature, motor activity

\section{RESUMO}

Este estudo visa determinar a relação entre indicadores de atividade motora, fator de $\mathrm{pH}$, temperatura ruminal e retal em até 10 dias após o parto e analisar a possibilidade de utilizar os parâmetros estudados como sinais prognósticos para o diagnóstico de acidose ruminal subaguda (SARA). As medições foram feitas usando bolus com sensores projetados para monitorar a saúde das vacas. A atividade motora, o fator de $\mathrm{pH}$ e a temperatura ruminal de 10 vacas foram medidos durante 10 dias em intervalos de medição de 60 segundos. A seguir, os pesquisadores calcularam os valores médios das leituras obtidas, que foram divididos em 2 grupos de acordo com um intervalo de medição a cada 12 horas. A temperatura retal foi medida com um termômetro veterinário a cada 12 horas (às $8 \mathrm{~h}$ e às $20 \mathrm{~h}$ ). Como resultado, foram obtidas 200 medições. As estatísticas de amostragem descritiva foram calculadas usando o programa SPSS Statistics. Um aumento na atividade motora reduz o nível de $\mathrm{pH}$ do ambiente ruminal. A redução do fator de $\mathrm{pH}$ do ambiente ruminal leva a um aumento da temperatura ruminal. Existe uma correlação positiva estatisticamente significativa entre a temperatura ruminal e retal. A nosologia com SARA pode ser prevista medindo a atividade motora e a temperatura retal de vacas leiteiras.

Palavras-chave: gado, rúmen, SARA, fator de $\mathrm{pH}$, temperatura, atividade motora

\section{INTRODUCTION}

Sub-acute rumen acidosis (SARA) is a widespread disease in cattle and other ruminants, characterized by increased production of lactic acid in the rumen and an acid-base disbalance in the body. This happens due to eating a large amount of feed rich in easily digestible carbohydrates but with an insufficient number of roughages (Dorosh, 2007). The SARA symptoms in cattle are very diverse. The first stage is

Recebido em 29 de agosto de 2020

Aceito em 27 de outubro de 2020

*Autor para correspondência (corresponding author)

E-mail: fvladimirov21@gmail.com 
characterized by loss of appetite, weak or sometimes completely absent rumen motion, the body temperature drops below normal, but after 4-5 days, it may increase due to stomach inflammation. Affected animals suffer from tachycardia (increased heart rate), diarrhea, and anuria (disuria) (Mikhailova et al., 2017).

The feed acidity determines the $\mathrm{pH}$ factor of the rumen environment. Gengler et al. (2010) observed a significant negative correlation $(\mathrm{R} 2=$ 0.77 ) between the $\mathrm{pH}$ factor of the rumen environment and its temperature. When the $\mathrm{pH}$ factor of the rumen environment decreased, an increase in ruminal temperature was noticed. Therefore, by measuring ruminal temperature, the $\mathrm{pH}$ level can be evaluated, which ensures the timely diagnosis of SARA (Alzahal et al., 2008). As practice shows, several methods use the $\mathrm{pH}$ factor of the rumen environment in cattle. The disadvantages of obtaining contents through a probe include the risk of mixing saliva, the procedure complexity, and the fact that the sample is "removed" from the surface of the feed mass in the rumen (the $\mathrm{pH}$ factor on the surface and in the middle may vary). In previous studies, it was found that as saliva got into a ruminal fluid sample, the $\mathrm{pH}$ readings turned out to be 0.5 units higher (Strabel et al., 2007).

Experts have recently developed boluses with sensors to measure the $\mathrm{pH}$ factor, temperature and motor activity. These boluses are inserted orally into a cow's rumen to monitor these indicators throughout the life. The obtained readings are transmitted to the transceiver (Keunen et al., 2002), and then to the cloud storage to be processed using algorithms and mathematical models and finally displayed as a graph in the application or interpreted into text messages (Alzahal et al., 2008). The reliability of real-time monitoring of the rumen $\mathrm{pH}$ factor as compared with other methods for assessing the risk of SARA is significantly higher (Gasteiner et al., 2012).

This method of evaluating the rumen $\mathrm{pH}$ factor in cattle was used in several scientific studies. Duffield et al. (2004) described and evaluated a method for continuous long-term monitoring the $\mathrm{pH}$ factor of the rumen environment, which uses a wireless data transmission unit. Antanaitis et al. (2018) found that temperature and $\mathrm{pH}$ readings of the rumen environment can be used as a probability predictor of reproductive success.
Antanaitis et al. (2016) revealed a correlation between rectal temperature, ruminal temperature, and the $\mathrm{pH}$ factor of the rumen environment. This study aims to determine the relationship between indicators of the motor activity, $\mathrm{pH}$ factor, ruminal temperature, and rectal temperature within 10 days after calving and analyzing the feasibility of the studied parameters.

\section{MATERIALS AND METHODS}

The study was conducted for ten dairy cows of the Holstein breed (Russia, the Yaroslavl region, JSC Voshchazhnikovo Agricultural Holding). In total, the herd consisted of 1317 dairy cows. A group of ten heads was formed according to the following criteria: all cows had a post calving period of up to 10 days, the same diet and housing conditions, the age of 2-3 lactations and weight not lower than $350 \mathrm{~kg}$, average milk yield at lactation peaks amounts to $30( \pm 3) \mathrm{kg} / \mathrm{day}$. The daily ration consisted of alfalfa hay $(2.5 \mathrm{~kg})$, corn silage $(16.0 \mathrm{~kg})$, alfalfa haylage $(12.0 \mathrm{~kg})$, propylene glycol $(0.2 \mathrm{~kg})$, glycerin $(0.15 \mathrm{~kg})$, and mixed feed $(8.78 \mathrm{~kg})$.

Before the study, the selected cows were examined in accordance with the clinical study order and were found completely healthy. The average body weight of the studied cows was 534 $( \pm 2.05) \mathrm{kg}$. Clinical signs of SARA (diarrhea, decreased appetite, and low level of rumination) were not observed. The motor activity, temperature, and $\mathrm{pH}$ factor were measured using an internal cattle health monitoring system (smaXtec animal care GmbH, Graz, Austria), which were preinserted in the studied cows. Boluses were orally inserted into cows with a mass of more than $350 \mathrm{~kg}$. The chosen polycarbonate case material was resistant to ruminal fluid, and the internal protective metal casing prevented mechanical damage. The bolus pH meter was calibrated using a buffer solution prior to insertion.

Data were monitored through a radio transmitter on the ISM band (433 MHz). The obtained readings of the motor activity, $\mathrm{pH}$ factor and ruminal temperature were transmitted through the base station to a server via a GSM or Ethernet cable module. The server processed the transmitted data using algorithms and a mathematical model and displayed the results in the form of graphs and messages on a computer or 
smartphone. The readings of ten cows were taken on a total of 10 days with the measurement interval of every 60 seconds. The entire array of measured indicators was transmitted to the server every 10 minutes. Then, the average values of the obtained readings were calculated and divided into 2 groups according to a measurement interval of every 12 hours. All data were uploaded from the system software database. Rectal temperature was measured using a veterinary thermometer (Genia Digiflash Thermometer for Pets \& Large Animals, St. Hilaire de Chaléons, France) twice a day (at 8 am and 8 pm), 200 measurements were taken.

Descriptive sampling statistics (arithmetic mean \pm standard error) were calculated using the Windows program, IBM SPSS Statistics 23 (IBM..., 2017). The relationship between the indicators was analyzed using the Pearson coefficient and the linear regression equation: $y=$ $\mathrm{bx}+\mathrm{a}$, where $\mathrm{x}-\mathrm{an}$ independent variable (predictor), y - a dependent variable (response variable); b - an angular coefficient (gradient of the estimated line), and a - a free term (intersection) of the estimation line, i.e. $\mathrm{y}$, when $\mathrm{x}$ $=0$. Coefficient of determination $\left(\mathrm{R}^{2}\right)$ was determined as a statistical measure of the data proximity to the fitted regression line. The data were considered reliable from a statistical point of view in case of $\mathrm{P}<0.05$.

\section{RESULTS}

The average $\mathrm{pH}$ of the rumen environment was $6.40( \pm 0.14)$, and the ruminal temperature was $39.41^{\circ} \mathrm{C}( \pm 0.17)$. The average level of the motor activity index was $9.05( \pm 1.63)$, and the rectal temperature was $39.42{ }^{\circ} \mathrm{C}( \pm 0.17)$. The relationship between the indicators of rectal temperature, motor activity, temperature and $\mathrm{pH}$ factor of the rumen environment of ten Holstein cows having the same diet and housing conditions observed during the study are presented in Table 1.

Table 1. Relationship (Pearson's correlation, r) between the indicators of physical activity, rectal temperature, $\mathrm{pH}$ and the temperature of rumen environment

\begin{tabular}{|c|c|c|c|c|}
\hline & Characteristics & $\mathrm{RpH}$ & RT & Act \\
\hline RT & $\begin{array}{l}\text { Pearson correlation } \\
\text { (two-tailed) }\end{array}$ & $\begin{array}{c}-0.932 * * \\
0.0001\end{array}$ & - & - \\
\hline Act & $\begin{array}{l}\text { Pearson correlation } \\
\quad \text { (two-tailed) }\end{array}$ & $\begin{array}{c}-0.263 * * \\
0.001\end{array}$ & $\begin{array}{c}0.647 * * \\
0.0001\end{array}$ & - \\
\hline RecT & $\begin{array}{l}\text { Pearson correlation } \\
\quad \text { (two-tailed) }\end{array}$ & $\begin{array}{c}-0.140 * * \\
0.001\end{array}$ & $\begin{array}{c}0.864 * * \\
0.0001\end{array}$ & $\begin{array}{c}0.628 * * \\
0.003\end{array}$ \\
\hline
\end{tabular}

The following correlations have been revealed: a negative statistically significant correlation $(\mathrm{r}=$ 0.932, $\mathrm{P}<0.01$ ) between the $\mathrm{pH}$ factor of the rumen environment and motor activity. An increase in motor activity helps to reduce the ruminal $\mathrm{pH}$ factor. Positive statistically significant correlation $(\mathrm{r}=0.647, \mathrm{P}<0.001)$ was revealed between ruminal temperature and motor activity. An increase in motor activity leads to an increase in ruminal temperature.

A positive statistically significant correlation $(\mathrm{r}=$ $0.628, \quad \mathrm{P}<0.001)$ was found between rectal temperature and motor activity. An increase in motor activity leads to an increase in rectal temperature. A negative statistically significant correlation $(\mathrm{r}=-0.932, \mathrm{P}<0.001)$ has been observed between ruminal temperature and the $\mathrm{pH}$ factor of the rumen environment. A decrease in the $\mathrm{pH}$ factor of the rumen environment leads to an increase in ruminal temperature. A negative statistically significant correlation $(\mathrm{r}=-0.140$, $\mathrm{P}<0.05)$ has been found between rectal temperature and the $\mathrm{pH}$ factor of the rumen environment.

A decrease in the $\mathrm{pH}$ factor of the rumen environment leads to an increase in rectal temperature. A positive statistically significant correlation $(r=0.864, \mathrm{P}<0.001)$ has been revealed between rectal and ruminal temperature. As ruminal temperature increases, rectal temperature increases too. The analysis of linear regression (Figure 1) has shown a regular linear increase in ruminal temperature along with a decrease in the $\mathrm{pH}$ level of the rumen environment $(\mathrm{y}=38.96+$ $\left.0.83^{*} \mathrm{x}\right)$. 


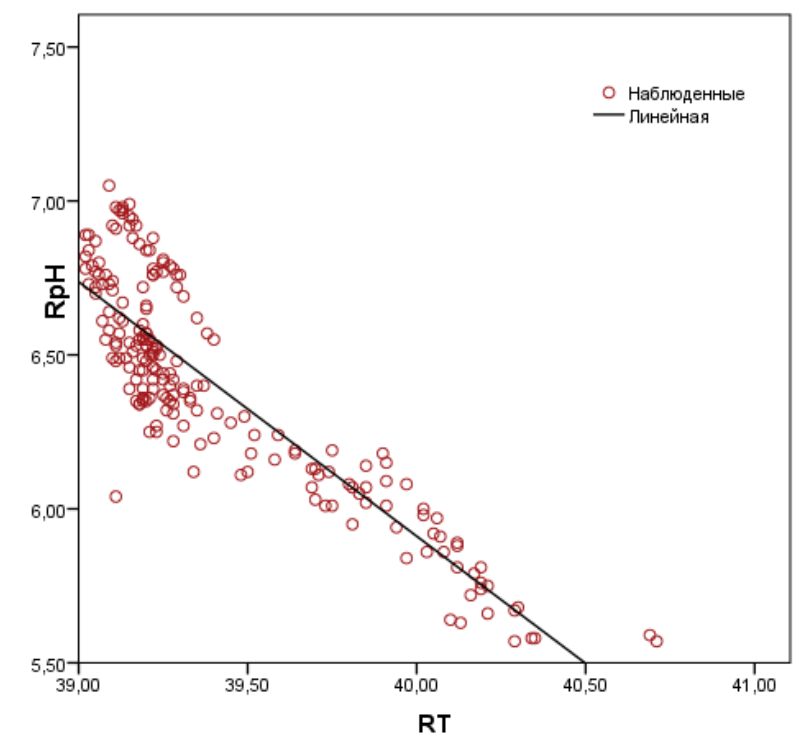

Figure 1. Analysis of the correlation between $\mathrm{pH}$ and ruminal temperature of ten Holstein cows under study, having the same diet and housing conditions. Footnotes: RpH: pH of the cicatricial medium, RT temperature of the cicatricial medium.

\section{DISCUSSION}

The study results have shown a negative statistically significant correlation $(r=-0.263$, $\mathrm{P}<0.01)$ between the $\mathrm{pH}$ factor of the rumen environment and motor activity. Kalyuzhny (1996 in his research work indicates that at the initial stage of SARA development, cows exhibit restless behavior (agitation). This is especially true for cows in the post-calving period when they are most susceptible to diseases due to weakened immunity. These cows were characterized by a low $\mathrm{pH}$ factor and, after some time, they showed the first signs of SARA (diarrhea, anuria, and fever). In conclusion, he states that monitoring the motor activity of cows in the post-calving period may contribute to the timely detection of SARA.

We have also confirmed the hypothesis of a high correlation between the $\mathrm{pH}$ factor and ruminal temperature of cattle put forward by Alzahal et al. (2008), as well as Antanaitis et al. (2016) in their scientific works. Their study results showed a negative statistically significant between ruminal temperature and the $\mathrm{pH}$ factor of the rumen environment. AlZahal et al. (2008) obtained a correlation of $\mathrm{r}=-0.46$ between the $\mathrm{pH}$ factor and the rumen environment temperature, using a device for simultaneous monitoring the temperature and $\mathrm{pH}$ factor of the rumen environment in dairy cows. Still this result may have been obtained due to the close location of two sensors. The authors got an equation for predicting the $\mathrm{pH}$ level of the rumen environment by monitoring ruminal temperature, and thus discussed the possibility of using ruminal temperature as an indicator for SARA detection in cows.

Antanaitis et al. (2016) observed a negative statistically significant correlation of $r=-0.199$ between the $\mathrm{pH}$ factor of the rumen environment and ruminal temperature using the SmaXtec health monitoring system. They concluded that the SARA nosology can be predicted by measuring ruminal temperature. Bewley et al. (2008) reported in their research paper that they obtained a high correlation $(r=0.65)$ between ruminal and rectal temperature in dairy cows as they used a large number of paired samples taken over several seasons. Alzahal et al. (2008) reported a significant increase in ruminal temperature due to feeding a large amount of grain as compared to a mixed hay diet.

Burns et al. (2002) conducted a similar study with cows, which were about to come into a sexual hunt. As a result, Sievers et al. (2005) obtained a correlation of $r=0.50$ between ruminal and rectal temperature. Moreover, in their previous study, they made use of boluses to monitor cattle health and obtained a high correlation $(r=0.92)$ between ruminal and rectal temperature (Sievers et al. 2005). Drillich et al. (2001) in their research 
concluded that regular measurement of the body temperature can be very useful for the daily monitoring of cattle health.

\section{CONCLUSIONS}

The following conclusions can be drawn from the results obtained. The research has proved that an increase in motor activity contributes to a decrease in the $\mathrm{pH}$ of the rumen environment. In its turn, an increase in physical activity leads to an increase in the temperature of the cicatricial environment. Also, an increase in physical activity leads to an increase in rectal temperature. A decrease in the $\mathrm{pH}$ of the rumen environment leads to an increase in its temperature, while a decrease in the $\mathrm{pH}$ of the rumen environment leads to an increase in rectal temperature. As the temperature of the rumen contents increases, the rectal temperature increases too. Linear regression analysis has shown a regular linear increase in the temperature of the ruminal environment with a decrease in its $\mathrm{pH}(\mathrm{y}=38.96$ $\left.+0.83^{*} \mathrm{x}\right)$. Thus, as the study results show, SARA can be predicted by measuring the motion and rectal temperature of dairy cows. Thus, the research results have confirmed the hypothesis put forward by Kalyuzhny that SARA can be predicted by measuring the motor activity of animals, as well as the hypothesis put forward by Antanaitis et al. that measuring rectal temperature can also help predict the contraction of SARA in dairy cows. The bolus system used to measure locomotion, temperature and $\mathrm{pH}$ has proven to be very useful for monitoring the physiological state of cattle. However, in order for the system to give accurate recommendations to livestock breeders, it is necessary to refine the existing mathematical models and algorithms for these purposes, which would provide for timely identification of deviations in their health indicators. This issue requires further research.

\section{REFERENCES}

ALZAHAL, O.; KEBREAB, E.; FRANCE, J. et al. Ruminal temperature may aid in the detection of subacute ruminal acidosis. J. Dairy Sci., v.91, p.202-207, 2008.

ANTANAITIS, R.; VIDA, J.; RUTKAUSKAS, A. et al. Reticuloruminal temperature and $\mathrm{pH}$ as indicators of the likelihood of reproductive success. J. Dairy Res., v.85, p.23-26, 2018.
ANTANAITIS, $\quad$ R.; $\quad$ ZILAITIS, $\quad$ V.; JUOZAITIENE, V.; STOSKUS R. Usefulness of acidity and temperature of the rumen and abomasum in diagnosing SARA in dairy cows after calving. Pol. J. Vet. Sci., v.19, p.553-558, 2016.

BEWLEY, J.M.; EINSTEIN, M.E.; GROTT, M.W.; SCHUTZ, M.M. Comparison of reticular and rectal core body temperatures in lactating dairy cows. J. Dairy Sci., v.91, p.4661-4672, 2008.

BURNS, P.; WAILES, W.; BAKER, P. Changes in reticular and rectal temperature during the periestrous period in cows. J. Anim. Sci., v.80, p.128-129, 2002.

DOROSH, M.V. Bolezni krupnogo rogatogo skota [Cattle diseases]. Russian: Veterinary Medicine Press, 2007.

DRILLICH, M.; BEETZ, O.; PFUTZNER, A. et al. Evaluation of a systemic antibiotic treatment of toxic puerperal metritis in dairy cows. J. Dairy Sci., v.84, p.2010-2017, 2001.

DUFFIELD, T.; PLAIZIER, J.C.; FAIRFIELD, A. Comparison of techniques for measurement of rumen $\mathrm{pH}$ in lactating dairy cows. J. Dairy Sci., v.87 p.59-66, 2004.

GASTEINER, J.; GUGGENBERGER, T.; HAUSLER, J.; STEINWIDDER, A. Continuous and long-term measurement of reticuloruminal $\mathrm{pH}$ in grazing dairy cows by an indwelling and wireless data transmitting unit. Vet. Med. Int., v.1155, p.1-7, 2012.

GENGLER, W.R.; MARTZ, F.A.; JOHNSON, H.D. Effect of temperature on food and water intake and rumen fermentation. J. Dairy Sci., v.53, p.434-437, 2010.

IBM SPSS statistics for Windows. Version 25.0. Armonk, NY: IBM Corp, 2017.

KALYUZHNY, I.I. Acidoz rubca krupnogo rogatogo skota [Rumen acidosis in cattle]. Volgograd, Russia: Publishing House Press, 1996.

KEUNEN, J.E.; PLAIZIER, J.C.; KYRIAZAKIS, L. Effects of a subacute ruminal acidosis model on the diet selection of dairy cows. J. Dairy Sci., v.85, p.3304-3313, 2002. 
MIKHAILOVA, I.I.; EVGLEVSKIY, A.A.; LESHENKO, T.R. et al. Profilaktika metabolicheskogo acidoza u korov pri silosnokoncentratnom tipe kormleniya [Prevention of metabolic acidosis in cows under a silageconcentrate feeding system]. Vet. J., v.4, p.5-7, 2017.

SIEVERS, A.K.; KRISTENSEN, N.B.; LAUE, H.J.; WOLFFRAM, S. Development of an intraruminal device for data sampling and transmission. J. Anim. Sci., v.13, p.207-210, 2005.
STRABEL, D.; EWY, A.; KAUFMANN, T. et al. Rumenozentese: eine geeignete Methode zur $\mathrm{pH}$ Bestimmung im Pansensaft beim Rind? Swiss Arch. Vet. Med., v.149, p.301-306, 2007. 